\title{
PENGARUH LAMA AGING TERHADAP SIFAT FISIK, KIMIA, DAN AKTIVITAS ANTIOKSIDAN PRODUK BAWANG HITAM LANANG
}

\section{Effect of Aging Time on Physical, Chemical, and Antioxidant Activity of Single Clove Black Garlic Product}

\author{
Rouzni Zhafira \\ Jurusan Teknologi Hasil Pertanian, FTP Universitas Brawijaya Malang \\ JI. Veteran, Malang 65145 \\ *Penulis Korespondensi, email: rouznizhafira1994@gmail.com
}

\begin{abstract}
ABSTRAK
Aged garlic atau yang lebih dikenal di pasaran sebagai bawang hitam merupakan produk bawang putih yang diberi perlakuan panas dalam kurun waktu tertentu. Tujuan dari penelitian ini adalah untuk mengkaji sifat fisik, kimia, dan aktivitas antioksidan produk bawang hitam dari jenis bawang hitam lanang yang diberi perlakuan panas dengan suhu $\pm 60^{\circ} \mathrm{C}$. Metode penelitian yang digunakan yaitu Rancangan Acak Kelompok (RAK) satu faktor yaitu lama aging bawang putih lanang yang terdiri dari 6 perlakuan yaitu 0 hari, 3 hari, 6 hari, 9 hari, 12 hari, dan 15 hari. Lama aging memberikan pengaruh nyata $(\alpha=0.05)$ terhadap kadar air, $\mathrm{pH}$, total fenol, total flavonoid, dan nilai kekuningan pada produk bawang hitam lanang sedangkan lama aging tidak berpengaruh nyata terhadap aktivitas antioksidan, nilai kecerahan, dan nilai kemerahan. Hasil penentuan perlakuan terbaik pada produk bawang hitam lanang didapatkan dengan lama aging 15 hari dengan parameter dan nilainya sebesar: kadar air $45.02 \%$ (bb), pH 3.93, aktivitas antioksidan $\left(\mathrm{IC}_{50}\right) 3.475 \mathrm{mg} / \mathrm{mL}$, total fenol $13.68 \mathrm{mg}$ $\mathrm{GAE} / \mathrm{g}$, total flavonoid $0.76 \mathrm{mg} \mathrm{GAE} / \mathrm{g}$, nilai L (kecerahan) 26.86, nilai a+ (kemerahan) 0.46 , dan nilai b+ (kekuningan) 1.7.
\end{abstract}

Kata Kunci: antioksidan, bawang hitam lanang, lama aging

\section{ABSTRACT}

Aged garlic, well-known as black garlic, is a heat treated garlic product with temperature $\pm 60^{\circ} \mathrm{C}$. The purpose of this study was to determine the effect of the treatment to physical and chemical characteristics as well as antioxidant activity of single clove black garlic produced. This research used Randomized Block Design (RAK) method using one factor. The factor of the research is aging time of single clove garlic, which consists of 6 level of treatments $(0,3$, $6,9,12$, and 15 days). Aging time significantly affects $(\alpha=0.05)$ water content, $p H$, total phenol content, total flavonoid content, and yellowness but it doesn't significantly effect to antioxidant activity, brightness, and redness. The best treatment of single clove black garlic product obtained was 15 days aging treatment. The product characteristics were water content of $45.02 \% \mathrm{v} / \mathrm{w}, 3.93 \mathrm{pH}$, antioxidant activity (IC50) of $3.475 \mathrm{mg} / \mathrm{mL}$, total phenol of $13.68 \mathrm{mg}$ $\mathrm{GAE} / \mathrm{g}$, total flavonoids of $0.76 \mathrm{mg} \mathrm{GAE} / \mathrm{g}, \mathrm{L}$ (brightness) of 26.86, a+ (redness) of 0.46, and b+ (yellowish) value of 1.7 .

Keywords: aging time, antioxidant, single clove black garlic

\section{PENDAHULUAN}

Aged garlic atau yang lebih dikenal di pasaran sebagai black garlic merupakan produk bawang putih yang diberi perlakuan panas pada suhu $65^{\circ}-80^{\circ} \mathrm{C}$ selama $30-40$ hari (Wang et al., 2010). Selama proses aging, senyawa allicin berubah menjadi komponen antioksidan seperti S-allyl cystein (SAC), tetrahydro- $\beta$-carbolines, alkaloids, dan flavonoid sehingga 
produk bawang hitam ini tidak memiliki flavor yang kuat seperti bawang putih mentah. Selain itu produk bawang hitam memiliki warna cokelat gelap dan rasa manis segar dikarenakan bawang putih mengalami reaksi Maillard (Sook et al., 2014).

Proses terbentuknya bawang hitam lanang karena adanya proses aging atau proses pemeraman pada suhu $\pm 60^{\circ} \mathrm{C}$. Salah satu faktor proses aging adalah lama waktu yang digunakan. Lama waktu yang digunakan untuk proses aging bawang putih lanang akan mempengaruhi kandungan bioaktifnya. Umumnya waktu aging dihentikan pada hari ke 13 atau hari ke 14 pemeraman dengan melihat perubahan warna yang semakin gelap seperti warna cokelat gelap pada produk bawang hitam lanang serta rasanya yang menjadi manis segar. Oleh karena itu perlu adanya penelitian tentang pengaruh lama aging terhadap sifat fisik, kimia, dan aktivitas antioksidan pada produk bawang hitam lanang.

\section{BAHAN DAN METODE}

\section{Alat}

Peralatan yang digunakan dalam penelitian ini meliputi mortar, neraca analitik (Denver Instrument), shaker (Heidolp Unimax 2010), sentrifugasi (Hettich EBA 20), tabung sentrifugasi, vortex (Turbo Mixer), spektrofotometer (Labomed Inc.), kuvet, oven (WTC Binder), desikator, freezer (Modena/MD30), lemari es (Electrolux), colour reader (Konica Minolta), pH meter, glassware, kertas saring, dan aluminium foil.

\section{Bahan}

Bahan utama yang digunakan dalam penelitian adalah bawang putih dan produk bawang hitam lanang yang dibeli dari UKM "As-Syifa" di Kabupaten Lamongan. Untuk bahan penunjang ekstraksi dan uji aktivitas antioksidan yang digunakan antara lain metanol pro analysis, aquades, hydrobat, DPPH, asam galat, reagen Folin Ciocalteau 10\% (Merck), $\mathrm{Na}_{2} \mathrm{CO}_{3}, \mathrm{NaNO}_{2}, \mathrm{AlCl}_{3}$, dan $\mathrm{NaOH}$.

\section{Pelaksanaan Penelitian}

Proses pembuatan produk bawang hitam lanang dilakukan di Kecamatan Tikung Kabupaten Lamongan oleh UKM "As-Syifa".

1. Sortasi

Sortasi dilakukan untuk memilih bawang putih lanang yang segar dan masih bagus dari kenampakan fisik dan teksturnya. Hasil sortasi bawang putih lanang yang memenuhi syarat akan digunakan sebagai bahan baku pembuatan produk bawang hitam lanang.

2. Pengupasan kulit luar

Dilakukan pengupasan kulit luar dari bawang putih lanang untuk membuang kulit luar yang kotor dan mengelupas sehingga didapatkan bawang putih lanang yang masih menempel dengan kulit arinya.

3. Aging atau pemeraman

Proses aging dilakukan selama 3 hari, 6 hari, 9 hari, 12 hari, dan 15 hari. Suhu yang digunakan untuk pemeraman bawang putih lanang adalah $\pm 60^{\circ} \mathrm{C}$ di dalam magic jar yang telah diletakkan kain katun yang bertujuan untuk menyerap uap yang terdapat di dalam magic jar. Selama proses aging setiap harinya dilakukan pengecekan suhu dengan termometer dan pembalikan atau pengadukan bahan dengan tujuan sampel mendapatkan panas yang merata.

\section{Prosedur Analisis}

Proses analisis produk bawang hitam lanang meliputi :

1. Analisis kadar air metode oven kering (AOAC, 1984)

2. Analisis $\mathrm{pH}$ (AOAC, 1990)

3. Analisis warna dengan color reader (Yuwono dan Susanto, 1998)

4. Uji aktivitas antioksidan metode DPPH (Molyneux, 2003)

5. Total fenol (Huang et al., 2005)

6. Total flavonoid (Hui, 2009) 


\section{Metode Penelitian}

Metode penelitian yang digunakan adalah Rancangan Acak Kelompok (RAK) dengan menggunakan satu faktor yaitu lama aging bawang putih lanang yang terdiri dari 6 perlakuan yaitu aging 0 hari, 3 hari, 6 hari, 9 hari, 12 hari, dan 15 hari. Pengulangan dilakukan sebanyak 3 kali sehingga diperoleh 18 satuan percobaan.

\section{Analisis Data}

Data hasil penelitian yang diperoleh akan dianalisis dengan metode ANOVA (Analysis of Variance) dan dilanjutkan dengan uji DMRT (Duncan's Multiple Range Test) dengan selang kepercayaan $95 \%$ jika pada hasil uji terdapat perbedaan. Selanjutnya penentuan perlakuan terbaik dengan menggunakan metode Zeleny.

\section{HASIL DAN PEMBAHASAN}

\section{Kadar Air}

Berdasarkan analisis kadar air pada bawang hitam lanang menunjukan penurunan seiring lamanya proses aging. Rerata nilai kadar air dapat dilihat pada Tabel 1.

Tabel 1. Rerata Kadar Air Produk Bawang Hitam Lanang Selama Proses Aging

\begin{tabular}{ccc}
\hline Lama aging (hari) & Kadar air (\%) & DMRT 5\% \\
\hline 0 & $57.53 \pm 3.35 \mathrm{e}$ & \\
3 & $5656 \pm 3.39 \mathrm{de}$ & 3.82 \\
6 & $53.48 \pm 3.65 \mathrm{cde}$ & 3.78 \\
9 & $50.35 \pm 3.5 \mathrm{bcde}$ & 3.72 \\
12 & $49.92 \pm 4.36 \mathrm{~b}$ & 3.67 \\
15 & $45.02 \pm 4.41 \mathrm{a}$ & 3.47 \\
\hline Keterangan: Angka yang disertai dengan notasi berbeda menunjukkan berbeda nyata $(\alpha=0.05)$
\end{tabular}

Penurunan kadar air terjadi seiring lamanya proses aging yang menggunakan suhu $\pm 60^{\circ} \mathrm{C}$ akan menguapkan kadar air dalam bahan sehingga tekstur produk bawang hitam lanang menjadi lunak dibandingkan dengan tekstur bahan baku yang masih keras. Menurut Muchtadi (1992), penyimpanan bahan pangan pada suhu tinggi menyebabkan proses fisiologis meningkat sehingga mengakibatkan terjadinya proses respirasi dan proses transpirasi. Proses respirasi merupakan proses katabolisme dengan tujuan memperoleh energi yang diperlukan untuk proses kehidupan sedangkan proses transpirasi adalah proses kehilangan air dalam bentuk gas dari jaringan hidup. Berdasarkan analisis ragam dengan selang kepercayaan 95\%, lama aging memberikan pengaruh nyata terhadap kadar air.

Tabel 1 menunjukkan bahwa kadar air produk bawang hitam lanang berpengaruh nyata terhadap lama aging. Pada proses pengovenan, kadar air menurun karena adanya penguapan. Semakin lama pemanasan menyebabkan massa air dalam bahan ikut menguap. Menurut Ratnasari et al. (2014) menjelaskan bahwa air menguap melalui permukaan bahan sedangkan air yang terdapat di bagian tengah akan merembes ke bagian permukaan kemudian menguap. Untuk mempercepat pengeringan pada umumnya bahan akan dipotongpotong atau dihaluskan. Hal ini berkaitan dengan luas permukaan bahan dimana semakin luas permukaan bahan, semakin besar permukaan yang kontak langsung dengan panas, sehingga mempercepat proses penguapan yang terjadi.

\section{pH}

Hasil analisis $\mathrm{pH}$ menunjukkan penurunan seiring lamanya proses aging. $\mathrm{pH}$ tertinggi adalah pada bahan baku (bawang putih lanang) sebesar 6.03 sedangkan $\mathrm{pH}$ terendah adalah produk bawang hitam lanang yang diaging selama 15 hari sebesar 3.93. Rerata $\mathrm{pH}$ produk bawang hitam lanang tersaji pada Tabel 2. 
Tabel 2. Rerata pH Produk Bawang Hitam Lanang Selama Proses Aging

\begin{tabular}{ccc}
\hline Lama aging (hari) & $\mathbf{p H}$ & DMRT 5\% \\
\hline 0 & $6.03 \pm 0.12 \mathrm{e}$ & \\
3 & $5.57 \pm 0.06 \mathrm{de}$ & 0.22 \\
6 & $4.87 \pm 0.15 \mathrm{~cd}$ & 0.22 \\
9 & $4.33 \pm 0.25 \mathrm{bc}$ & 0.22 \\
12 & $4.13 \pm 0.15 \mathrm{~b}$ & 0.21 \\
15 & $3.93 \pm 0.06 \mathrm{a}$ & 0.20 \\
\hline
\end{tabular}

Keterangan: Angka yang disertai dengan notasi berbeda menunjukkan berbeda nyata $(\alpha=0.05)$

Terjadinya penurunan $\mathrm{pH}$ dikarenakan adanya proses respirasi selama proses aging. Secara fisiologis, adanya proses respirasi akan menyebabkan pemakaian asam-asam organik sehingga akan menurunkan total asam pada produk bawang hitam. Pada proses respirasi akan mentransformasi asam piruvat dan asam-asam organik lainnya secara aerobik menjadi $\mathrm{CO}_{2}, \mathrm{H}_{2} \mathrm{O}$, dan energi (ATP) (Muchtadi, 1992). Efek dari penurunan $\mathrm{pH}$ akan mempengaruhi aktivitas enzim sehingga akan memberikan flavor khas bawang putih lanang. Berdasarkan analisis ragam dengan selang kepercayaan 95\%, lama aging memberikan pengaruh nyata terhadap $\mathrm{pH}$.

\section{Total Flavonoid}

Penentuan kadar total flavonoid produk bawang hitam lanang menggunakan metode spektrofotometer dengan penambahan larutan aluminium klorida. Berikut disajikan rerata nilai total flavonoid pada Tabel 3.

Tabel 3. Tabel Rerata Total Flavonoid Produk Bawang Hitam Lanang Selama Aging

\begin{tabular}{ccc}
\hline Lama aging (hari) & TFC (mg GAE/g) (bk) & DMRT 5\% \\
\hline 0 & $0.55 \pm 0.69 \mathrm{ab}$ & 0.10 \\
3 & $0.44 \pm 0.03 \mathrm{a}$ & 0.09 \\
6 & $0.7 \pm 0.13 \mathrm{~b}$ & 0.10 \\
9 & $0.61 \pm 0.09 \mathrm{ab}$ & 0.10 \\
12 & $0.94 \pm 0.06 \mathrm{c}$ & \\
15 & $0.76 \pm 0.07 \mathrm{bc}$ & 0.10
\end{tabular}

Keterangan: angka yang disertai dengan notasi berbeda menunjukkan berbeda nyata $(\alpha=0.05)$

Menurut Miean dan Mohamed (2001) diantara empat sub grup flavonoid bawang putih, flavonol ditemukan dengan konsentrasi tertinggi lalu diikuti dengan flavonon dan flavon kecuali pada sampel bawang putih segar. Flavonon adalah senyawa aromatik keton yang tidak berwarna dan sering ditemukan pada tanaman sebagai glikosida, sedangkan flavon adalah suatu senyawa kristalin tidak berwarna yang menjadi bahan dasar pigmen tumbuhan untuk warna putih atau kuning. Senyawa kaempferol dan naringenin tidak terdeteksi pada sampel apapun baik bahan baku bawang putih lanang maupun produk bawang hitam lanang. Konsentrasi senyawa flavonoid seperti myricetin, quercetin, dan apigenin tertinggi pada bawang putih. Gorinstein et al. (2008) menyatakan bahwa senyawa quercetin dan kaempferol hanya ditemukan pada bawang merah dan bawang putih. Adanya perbedaan senyawa flavonoid yang terdapat pada tiap sampel yang diberi perlakuan panas dikarenakan variasi nomer dan susunan grup hidroksil, terutama terjadi pada dihidroksilasi dengan posisi 3 dan 4 (Rice-Evans et al., 1996).

Berdasarkan analisis ragam dengan selang kepercayaan 95\%, lama aging memberikan pengaruh nyata terhadap total flavonoid diduga karena tingkat sensitivitas sampel terhadap panas yang diberikan selama proses aging. Proses pemanasan memiliki pengaruh besar terhadap ketersediannya flavonoid. Hal ini tergantung pada tingkat dan durasi pemanasan, tingkat sensitivitas bahan terhadap panas, dan lingkungan fisikokimia bahan (loannou et al., 2012). 


\section{Total Fenol}

Nilai total fenol pada bawang hitam lanang meningkat seiring lamanya proses aging. Rerata nilai total fenol dapat dilihat pada Tabel 4.

Tabel 4. Tabel Rerata Total Fenol Produk Bawang Hitam Lanang Selama Proses Aging

\begin{tabular}{ccc}
\hline Lama aging (hari) & TPC $(\mathbf{m g ~ G A E} / \mathbf{g}) \mathbf{( b k )}$ & DMRT 5\% \\
\hline 0 & $9.69 \pm 1.35 \mathrm{a}$ & 1.10 \\
3 & $10.22 \pm 1.48 \mathrm{a}$ & 1.15 \\
6 & $10.40 \pm 1.87 \mathrm{a}$ & 1.18 \\
9 & $11.8 \pm 1.68 \mathrm{~b}$ & 1.19 \\
12 & $13.85 \pm 245 \mathrm{~b}$ & 1.21 \\
15 & $13.68 \pm 2.29 \mathrm{~b}$ & \\
\hline
\end{tabular}

Terjadinya kenaikan total fenol dari bahan baku bawang putih lanang menjadi produk bawang hitam lanang menurut $\mathrm{Xu}$, et al. (2007) dikarenakan proses pemanasan komponen fenolik akan meningkatkan fraksi bebas asam fenol dimana akan terjadi penurunan ester, glikosida, dan ikatan ester. Dalam hal ini akan mempengaruhi penurunan nilai aktivitas antiokisdan $\left(\mathrm{IC}_{50}\right)$ berdasarkan ikatan esternya. Berdasarkan analisis ragam dengan selang kepercayaan $95 \%$, lama aging memberikan pengaruh nyata terhadap total fenol.

Kenaikan suhu akan meningkatkan permeabilitas dinding sel dan mengakibatkan peningkatan kelarutan dan difusi dari senyawa fenolik yang terekstrak. Peningkatan suhu juga menyebabkan peningkatan kadar total fenol sampai suhu tertentu, akan tetapi seiring meningkatnya suhu akan menyebabkan penurunan senyawa fenolik. Hal ini dikarenakan dekomposisi senyawa fenolik yang menyebabkan titik didih senyawa baru lebih mudah menguap (Bailon et al., 2003).

\section{Aktivitas Antioksidan}

Aktivitas antioksidan dinyatakan dengan nilai $\mathrm{IC}_{50}$ (Inhibitory Concentration) yang didefinisikan sebagai jumlah konsentrasi senyawa antioksidan yang dibutuhkan untuk menurunkan 50\% konsentrasi DPPH kehilangan karakter radikal bebasnya. Semakin kecil nilai $\mathrm{IC}_{50}$ menunjukkan semakin tinggi aktivitas antioksidannya (Molyneux, 2004). Rerata aktivitas antioksidan pada produk bawang hitam lanang tersaji pada Tabel 5.

Tabel 5. Tabel Rerata Aktivitas Antioksidan Produk Bawang Hitam Lanang Aging

\begin{tabular}{cc}
\hline Lama aging (hari) & IC $(\mathbf{m g} / \mathbf{g}) \mathbf{( b k})$ \\
0 & $42.00 \pm 18.11$ \\
3 & $29.58 \pm 16.71$ \\
6 & $13.45 \pm 6.11$ \\
9 & $6.22 \pm 2.58$ \\
12 & $3.48 \pm 2.17$ \\
15 & $3.48 \pm 0.21$ \\
\hline
\end{tabular}

Nilai $\mathrm{IC}_{50}$ pada produk bawang hitam lanang yang semakin kecil menunjukan bahwa aktivitas antioksidannya meningkat. Nilai $\mathrm{IC}_{50}$ bawang hitam lanang kurang dari 50 memiliki intensitas sangat aktif untuk menurunkan 50\% konsentrasi DPPH kehilangan karakter radikal bebasnya. Nilai $I_{50}$ tertinggi terdapat pada perlakuan dengan lama aging 12 hari sebesar $3.48 \mathrm{mg} / \mathrm{g}$, sedangkan nilai $\mathrm{IC}_{50}$ terendah terdapat pada bahan baku bawang putih lanang sebesar $42.00 \mathrm{mg} / \mathrm{g}$. Hal ini disebabkan semakin tinggi nilai total fenol pada produk bawang hitam lanang semakin rendah nilai $I_{C_{50}}$ ya. Hal ini dapat dibuktikan dengan dengan nilai total fenol pada sampel dengan lama aging 12 hari sebesar $13.85 \mathrm{mg} \mathrm{GAE} / \mathrm{g}$, sedangkan nilai total fenol pada bahan baku bawang putih lanang sebesar $9.67 \mathrm{mg} \mathrm{GAE} / \mathrm{g}$. 
Berdasarkan analisis ragam dengan selang kepercayaan 95\%, lama aging tidak memberikan pengaruh nyata terhadap aktivitas antioksidan. Menurut Morales dan Babel (2002), terdapat empat kemungkinan yang menyebabkan peningkatan aktivitas antioksidan setelah pemanasan atau pemasakan pada beberapa percobaan sayur, yaitu: (1) keluarnya sejumlah besar komponen antioksidan karena kerusakan dinding sel akibat panas, (2) terbentuknya sejumlah senyawa antioksidan kuat yang dapat menangkal radikal akibat reaksi kimia pada proses pemanasan, (3) penekanan kapasitas oksidasi dan antioksidan melalui proses thermal inaktivasi enzim-enzim oksidatif, dan/atau (4) pembentukan senyawa antioksidan non nutrien atau senyawa baru seperti produk reaksi Maillard yang memiliki aktivitas antioksidan.

\section{Warna}

Warna merupakan parameter fisik yang sangat penting terhadap bahan pangan yang dapat memberikan persepsi makan pada konsumen. Perubahan warna cokelat gelap pada bawang hitam lanang terjadi selama proses aging. Pengukuran warna pada produk bawang hitam lanang menggunakan colour reader dan nilai hasil pengukuran merupakan nilai yang berasal dari sistem Hunter. Parameter warna sistem Hunter terdiri dari tiga, yaitu kromatik (hue) yang ditulis dengan notasi $a^{*}$, intensitas warna ditulis dengan notasi $b^{*}$, dan kecerahan ditulis dengan notasi L. Notasi $a^{*}$ menunjukkan warna kromatik campuran merah- hijau, dimana nilai $\mathrm{a}(+)$ berkisar antara 0 sampai 100 yang merupakan warna merah, sedangkan nilai $a(-)$ berkisar 0 sampai -80 merupakan warna hijau. Notasi $b^{*}$ menunjukkan warna kromatik campuran biru-kuning, dimana nilai $b(+)$ berkisar antara 0 sampai 70 merupakan warna kuning dan nilai b(-) berkisar 0 sampai -80 merupakan warna biru (Andarwulan dkk., 2011; Jatmiko, 2014; Wardhani, 2014).

\section{Warna Kecerahan (L)}

Analisis warna kecerahan (L) bertujuan untuk mengetahui pengaruh lama aging terhadap tingkat kecerahan warna produk bawang hitam lanang. Nilai kecerahan tertinggi diperoleh pada bahan baku yaitu bawang putih lanang sebesar 51.23 sedangkan nilai kecerahan terendah diperoleh pada produk bawang hitam lanang dengan lama inkubasi 15 hari sebesar 26.86. Nilai kecerahan pada produk bawang hitam lanang menurun seiring lamanya aging. Rerata nilai kecerahan dapat dilihat pada Tabel 6.

Tabel 6. Tabel Rerata Nilai Kecerahan Produk Bawang Hitam Lanang Selama Aging

\begin{tabular}{cc}
\hline Lama aging (hari) & Nilai kecerahan \\
\hline 0 & $51.23 \pm 0.66$ \\
3 & $44.54 \pm 3.2$ \\
6 & $31.84 \pm 0.37$ \\
9 & $28.62 \pm 0.95$ \\
12 & $27.37 \pm 0.96$ \\
15 & $26.86 \pm 0.32$ \\
\hline angan: Angka yang disertai dengan notasi berbeda menunjukkan berbeda nyata $(\alpha=0.05)$
\end{tabular}

Terjadinya penurunan nilai kecerahan berkaitan dengan reaksi Maillard yang terjadi selama proses aging pada suhu $70^{\circ} \mathrm{C}$. Reaksi Maillard atau reaksi pencokelatan non enzimatis terjadi karena adanya reaksi antara gula pereduksi dengan gugus amin bebas dari asam amino atau protein. Produk akhir dari reaksi Maillard untuk setiap jalur reaksi adalah melanoidin. Melanoidin merupakan senyawa yang bertanggung jawab terhadap timbulnya warna cokelat pada makanan (Zhuang dan Sun, 2011). Berdasarkan analisis ragam dengan selang kepercayaan 95\%, lama aging tidak memberikan pengaruh nyata terhadap nilai kecerahan. Dalam hal ini lama aging memberikan pengaruh nyata terhadap nilai kecerahan produk bawang hitam lanang yang ditandai dengan terjadinya perubahan warna kuning cerah pada bahan baku yaitu bawang putih lanang menjadi produk bawang hitam lanang yang berwarna cokelat kehitaman. 


\section{Warna Kemerahan $\left(\mathbf{a}^{*}\right)$}

Nilai kemerahan pada produk bawang hitam lanang menurun seiring lamanya proses aging. Rerata nilai kemerahan dapat dilihat pada Tabel 7.

Tabel 7. Tabel Nilai Kemerahan Produk Bawang Hitam Lanang Selama Proses Aging

\begin{tabular}{cc}
\hline Lama aging (hari) & Nilai kemeraha \\
\hline 0 & $-3.79 \pm 8.49$ \\
3 & $9.3 \pm 3.02$ \\
6 & $4.77 \pm 1.79$ \\
9 & $2.76 \pm 2.09$ \\
12 & $0.89 \pm 2.35$ \\
15 & $0.46 \pm 11.76$
\end{tabular}

Keterangan: Angka yang disertai dengan notasi berbeda menunjukkan berbeda nyata $(\alpha=0.05)$

Terjadinya penurunan nilai kemerahan pada produk bawang hitam lanang berhubungan dengan reaksi Maillard yang terjadi selama proses aging. Produk dari reaksi Maillard berhubungan dengan peningkatan absorbansi panjang gelombang maksimum pada UVvisible spektroskopi. Berdasarkan analisis ragam dengan selang kepercayaan 95\%, lama aging tidak memberikan pengaruh nyata terhadap nilai kemerahan diduga karena pengaruh absorbansi cahaya lingkungan terhadap absorbansi sampel yang menggunakan colour reader sehingga sensitifitas penyerapan warna merah akan bias sehingga terjadi penurunan nilai kemerahan pada produk bawang hitam lanang, yang seharusnya semakin lama proses aging akan terjadi peningkatkan nilai kemerahan dikarenakan akumulasi senyawa melanoidin (Nursten, 2005).

\section{Warna Kekuningan}

Analisis warna kekuningan $\left(b^{*}\right)$ bertujuan untuk mengetahui pengaruh lama aging terhadap tingkat kekuningan warna produk bawang hitam lanang. Rerata nilai kekuningan $\left(b^{*}\right)$ produk bawang hitam lanang berkisar antara 19.43 hingga 1.7 dengan perlakuan lama aging 3 sampai dengan 15 hari. Nilai kekuningan pada produk bawang hitam lanang menurun seiring lamanya proses aging. Rerata nilai kekuningan dapat dilihat pada Tabel 8.

Tabel 8. Tabel Rerata Nilai Kekuningan Produk Bawang Hitam Lanang Selama Aging

\begin{tabular}{ccc}
\hline Lama aging (hari) & Nilai Kekuningan $\left(\mathbf{b}^{*}\right)$ & DMRT 5\% \\
\hline 0 & $19.43 \pm 2.01 \mathrm{~d}$ & \\
3 & $19.03 \pm 2.34 \mathrm{~cd}$ & 1.14 \\
6 & $7.05 \pm 1.36 \mathrm{bc}$ & 1.13 \\
9 & $4.09 \pm 1.76 \mathrm{ab}$ & 1.11 \\
12 & $1.96 \pm 1.32 \mathrm{a}$ & 1.08 \\
15 & $1.7 \pm 1.15 \mathrm{a}$ & 1.03 \\
\hline
\end{tabular}

Pembentukan reaksi Maillard tergantung kondisi proses seperti suhu dan waktu. Hal ini menyebabkan perubahan warna pada produk bawang hitam lanang yaitu terjadinya peningkatan nilai kemerahan dan penurunan tingkat kecerahan dan nilai kekuningan (Hardy et al., 1999). Penurunan nilai kekuningan ini erat hubungannya dengan nilai kecerahan yang juga semakin menurun.

Berdasarkan analisis ragam dengan selang kepercayaan 95\%, lama aging berpengaruh nyata terhadap nilai warna kekuningan. Lama aging memberikan pengaruh nyata terhadap nilai kekuningan diduga karena semakin lama proses aging akan memproduksi zat berwarna gelap yang didapat melalui kondensasi aldol, kondensasi aldehidamin, dan pembentukan komponen heterosiklik nitro sehingga terjadi penurunan nilai kekuningan pada produk bawang hitam lanang. 


\section{Penentuan Perlakuan Terbaik}

Penentuan perlakuan terbaik pada produk bawang hitam lanang menggunakan metode Zeleny. Hasil perhitungan perlakuan terbaik pada produk bawang hitam lanang didapatkan dengan lama aging 15 hari. Hal ini tersaji pada Tabel 9.

Tabel 9. Perlakuan Terbaik dengan Metode Zeleny Dibandingkan dengan Data Literatur

\begin{tabular}{lcc}
\hline \multicolumn{1}{c}{ Parameter } & Hasil Analisis & Data Literatur \\
\hline Kadar air (\%) & 45.02 & $31.77^{\mathrm{a}}$ \\
$\mathrm{pH}$ & 3.93 & $4.41^{\mathrm{a}}$ \\
Antioksidan $\left(\mathrm{IC}_{50}\right)$ & 3.48 & $1.24^{\mathrm{b}}$ \\
Fenol $(\mathrm{mg} \mathrm{GAE} / \mathrm{g})$ & 13.68 & $35.28^{\mathrm{a}}$ \\
Flavonoid (mg GAE/g) & 0.76 & $8.34^{\mathrm{a}}$ \\
Warna: Kecerahan (L) & 26.86 & $9.28^{\mathrm{a}}$ \\
Kemerahan (a+) & 0.46 & $5.45^{\mathrm{a}}$ \\
Kekuningan (b+) & 1.7 & $2.37^{\mathrm{a}}$ \\
\hline
\end{tabular}

Keterangan : Setiap data hasil analisis merupakan rerata dari 3 kali ulangan

Sumber : ${ }^{a}$ Choi et al. (2014)

${ }^{b}$ Kim et al. (2013)

Berdasarkan hasil analisis, kadar air bawang hitam sebesar $45.02 \pm 4.41$. Kadar air akan menurun seiring lamanya proses aging yang menggunakan suhu $\pm 60^{\circ} \mathrm{C}$ akan menguapkan kadar air dalam bahan. $\mathrm{pH}$ bawang hitam sebesar $3.93 \pm 0.06$. Terjadinya penurunan $\mathrm{pH}$ dikarenakan adanya respirasi selama proses aging. Perhitungan aktivitas antioksidan menggunakan $\mathrm{IC}_{50}$ dalam berat kering dimana kandungan antioksidan bawang hitam lanang sebesar $3.48 \pm 0.21 \mathrm{mg} / \mathrm{g}$ sedangkan nilai $I_{50}$ pada literatur sebesar $1.24 \pm 0.55 \mathrm{mg} / \mathrm{mL}$. Menurut Molyneux (2004) semakin kecil nilai $\mathrm{IC}_{50}$ suatu sampel menunjukkan semakin tinggi aktivitas antioksidannya. Total fenol hasil analisis dalam berat kering sebesar $13.68 \pm 2.29 \mathrm{mg}$ $\mathrm{GAE} / \mathrm{g}$ sedangkan pada literatur sebesar $35.28 \pm 0.32 \mathrm{mg}$ GAE/g. Terjadinya kenaikan total fenol pada bawang hitam lanang menurut $\mathrm{Xu}$ et al. (2007) adalah proses pemanasan komponen fenolik akan meningkatkan fraksi bebas asam fenol dimana akan terjadi penurunan ester, glikosida, dan ikatan ester.

Total flavonoid hasil analisis dalam berat kering sebesar $0.76 \pm 0.07 \mathrm{mg} \mathrm{GAE} / \mathrm{g}$ sedangkan pada literatur sebesar $8.34 \pm 0.61 \mathrm{mg} \mathrm{GAE} / \mathrm{g}$. Proses pemanasan mempunyai pengaruh besar terhadap flavonoid dimana tingkat dan lama pemanasan, sensitivitas terhadap panas serta sifat fisikokimia pada bahan pangan dapat meningkatkan dan menurunkan total flavonoid (Loannou, 2012). Analisis warna pada bawang hitam meliputi nilai L, a, b. Nilai L (kecerahan) sebesar 26.86; nilai a+ (kemerahan) sebesar 0.46; dan nilai b+ (kekuningan) sebesar 1.7. Perubahan warna bawang hitam ini dikarenakan adanya reaksi Maillard selama proses aging yang menyebabkan nilai kecerahan dan kekuningan menurun.

\section{SIMPULAN}

Dari hasil penelitian dan pembahasan dapat disimpulkan bahwa:

1. Lama aging memberikan pengaruh nyata $(\alpha=0.05)$ terhadap kadar air, $\mathrm{pH}$, total fenol, total flavonoid, dan nilai kekuningan pada produk bawang hitam lanang sedangkan lama aging tidak berpengaruh nyata terhadap aktivitas antioksidan, nilai kecerahan, dan nilai kemerahan.

2. Aktivitas antioksidan dinyatakan dengan nilai $\mathrm{IC}_{50}$ (Inhibitory Concentration). Nilai $\mathrm{IC}_{50}$ pada produk bawang hitam lanang semakin kecil menunjukan semakin tingginya aktivitas antioksidannya. Nilai $\mathrm{IC}_{50}$ tertinggi terdapat pada perlakuan dengan lama inkubasi 12 hari sebesar $3.47 \mathrm{mg} / \mathrm{g}$, sedangkan nilai $\mathrm{IC}_{50}$ terendah terdapat pada bahan baku bawang putih lanang sebesar $42.00 \mathrm{mg} / \mathrm{g}$.

3. Perlakuan terbaik terdapat pada produk bawang hitam lanang dengan lama inkubasi 15 hari. 


\section{DAFTAR PUSTAKA}

Andarwulan, N., Kusnandar, F., dan Herawati. D. 2011. Analisis Pangan. PT. Dian Rakyat. Jakarta.

Bailon, M. T., dan Santos, B. 2003. Polyphenols Extraction From Foods. Methods in Polyphenols Analysis. Royal Society of Chemistry. Cambridge, UK.

Gorinstein, S., Leontowicz, H., Leontowicz, M., Namiesnik, J., Najman, K., Drzewiecki, J., Cvikrova, M., Martincova, O., Katrich, E., and Trakhtenberg, S. 2008. Comparison of The Main Bioactive Compounds and Antioxidant Activities in Garlic and White and Red Onions After Treatment Protocols. J. Agric. Food Chem 56, 4418 - 4426.

Hardy, J., Parmentier, M., and Fanni, J. 1999. Functionality of Nutrients and Thermal Treatment of Food. Proc. Nutr. Soc. 58: 3, 579-585.

Ioannou, I., Hafsa, I., Hamdi, S., Charbonnel, C., and Ghoul, M. 2012. Review of The Effects of Food Processing and Formulation on Flavonol and Anthocyanins Behavior. J. Food Eng. 111:2, 208-217.

Jatmiko, G. P., dan Estiasih, T. 2014. Mie dari Umbi Kimpul (Xanthosoma sagittifolium): Kajian Pustaka. Pangan dan Argoindustri 2: 2, 127-134.

Molyneux, P. 2004. The Use of The Stable Free Radical Diphenylpicryl-hydrazyl (DPPH) for Estimating Antioxidant Activity. Songklanakarin Journal of Science and Technology 26: 2, 211-219.

Morales, F. J and Babel, M. B. 2002. Antiradical Efficiency of Mailard Reaction Mixtures in A Hydrophilic Media. J. Agric and Food Chem 50: 2788-2792.

Muchtadi, D. 1992. Fisiologi Pasca Panen Sayuran dan Buah-Buahan (Petunjuk Laboratorium). PAU Pangan dan Gizi Institut Pertanian Bogor. Bogor.

Nursten, H. 2005. The Maillard Reaction: Chemistry Biochemistry and Implications. UK: Cambridge. The Royal Society of Chemistry pp. $2-4$.

Ratnasari, dan Nirma. Y. 2014. Pengaruh Suhu dan Lama Perendaman Terhadap Laju Pengeringan Kacang Hijau pada Kinerja Alat Rotary Dryer. Thesis. Universitas Diponegoro Semarang.

Rice-Evans, C. A., Miller, N. J., and Paganga, G. 1996. Structure Antioxidant Activity Relationship of Flavonoids and Phenolic Acids. Free Radical Biology and Medicine 20: 3, 933-956.

Choi I. S., Cha, H. S., and Lee, Y. S. 2014. Physicochemical and Antioxidant Properties of Black Garlic. Molecules 19: 10,16811-16823.

Wang, D., Feng, Y., Liu, J., Yan, J., Wang, M., and Sasaki, Lu, C. 2010. Black Garlic (Allium sativum) Extracts Enhance the Immune System. Medicinal and Aromatic Plant Science and Biotechnology 4: 10, 37-40.

Wardhani, R. Z. 2014. Penyimpanan Suhu Rendah untuk Mempertahankan Mutu Daun Pohpo

han (Pilea melastomoides (Poir.) Wedd.). Skripsi. Institut Pertanian Bogor. Bogor.Xu, G., Ye, X., Chen, J., and Liu, D. 2007. Effect of Heat Treatment on The Phenolic Compounds and Antioxidant Capacity of Citrus Peel Extract. J. Agric. Food Chem 55: 2, 330-335. 